\title{
Pengaruh Pemanfaatan Mobile Instant Messaging Terhadap Self- Efficacy dan Kemampuan Kognitif Siswa pada Materi Hukum Newton
}

\author{
Rika Dwi Kurniati, Wayan Suana*, dan Nengah Maharta \\ Fakultas Keguruan dan IImu Pendidikan, Universitas Lampung \\ *E-mail: wsuane@gmail.com
}

\begin{abstract}
Abstrak
Penelitian ini bertujuan untuk mengetahui pengaruh pemanfaatan mobile instant messaging (MIM) WhatsApp terhadap self efficacy dan kemampuan kognitif siswa pada materi Hukum Newton. Desain penelitian yang digunakan adalah non-equivalent control group design. Penelitian ini menggunakan subyek siswa SMAN 9 Bandar Lampung kelas XI MIPA 1 sebagai kelas kontrol dan kelas XI MIPA 2 sebagai kelas eksperimen yang berjumlah masing-masing 30 siswa pada Semester Ganjil Tahun Ajaran 2018/2019. Teknik analisis data yang digunakan adalah independent sample t-test untuk uji parametrik dan Mann-Withney U-test untuk uji non parametrik. Berdasarkan hasil analisis data, diperoleh bahwa rata-rata post-test self efficacy pada kelas eksperimen 80,1 sedangkan pada kelas kontrol 67,06. Rata-rata postest kemampuan kognitif siswa pada kelas eksperimen 81,33 dan pada kelas kontrol 73,66. Perbedaan kedua kelas baik pada self efficacy dan kemampuan kognitif sangat signifikan dimana nilai kelas eksperimen lebih tinggi dibandingkan nilai kelas kontrol. Dengan demikian, dapat disimpulkan bahwa self efficacy dan kemampuan kognitif siswa yang memperoleh pembelajaran berbantuan MIM WhatsApp lebih baik dibandingkan dengan kelas yang tidak menggunakan WhatsApp.
\end{abstract}

Kata kunci: Kemampuan kognitif, Mobile Instant Messaging (MIM), Self-efficacy, WhatsApp

\section{PENDAHULUAN}

Pada era globalisasi saat ini perkembangan teknologi sangat pesat salah satunya dalam pergerseran metode komunikasi. Sebelum berkembangnya alat komunikasi, untuk memberi kabar kita menggunakan surat tetapi saat ini menggunakan pesan instan seluler yang memerlukan internet. Hampir setiap orang menggunakan internet dalam kehidupan sehari-hari. Hal ini diketahui dari hasil survei Asosiasi Penyelenggara Jasa Internet Indonesia (APJII) pada tahun 2017 penggunaan internet di Indonesia mencapai 143,26 juta jiwa Hampir seluruhnya menggunakan internet untuk akses chatting sebesar $89,35 \%$, share artikel atau video edukasi $21,73 \%$ dan kursus online 17,85 \% (APJII , 2017). Selama dekade terakhir orang-orang yang dikenal sebagai generasi internet sering menggunakan smartphone dalam kehidupan sehari-hari. Salah satunya digunakan untuk memberi kabar, bersosialisasi, bermain game, berbelanja, dan melakukan segalanya menggunakan smartphone (Bansal \& Joshi, 2014). Saat ini media sosial yang mencakup situs jejaring sosial dan MIM dianggap sebagai salah satu alat komunikasi yang paling penting (Abdelraheem \& Ahmed, 2018).

Pemanfaatan smartphone juga ditemukan dalam dunia pendidikan, teknologi media sosial menawarkan cara-cara modern dan kreatif untuk membangun lingkungan belajar sosial (Abdelraheem \& Ahmed, 2018). Aplikasi media sosial berupa grup diskusi dapat memicu dan meningkatkan interaksi antara instruktur dan siswa (Alabdulkareem, 2015; Barhoumi, 2015; Naidoo \& Kopung, 2016; Prescott dkk., 2013; Rambe \& Bere, 2013; Sobaih, 2016). Sejalan dengan penelitian Amry (2014) menyatakan bahwa pembelajaran menggunakan akses chatting atau biasa disebut dengan mobile instant messaging (MIM) dapat mendukung proses pembelajaran yang aktif. Manfaat menerapkan pembelajaran mobile adalah menyediakan wadah untuk siswa saling berdiskusi dan memperluas lingkungan belajar ke mana saja dan kapan saja (Crescente \& Lee, 2011).

Pembelajaran menggunakan mobile biaya yang dikeluarkan lebih murah, dan ukuran lebih kecil dan lebih ringan daripada menggunakan komputer (Stošić \& Bogdanović, 2013). Pembelajaran 
menggunakan perangkat seluler, siswa dapat membangun dan memiliki kesempatan untuk berbagi informasi dan pengetahuan dengan mudah (Pence, 2007). Selain itu, Amry (2014) menyatakan bahwa perangkat seluler memberikan mobilitas dan interaktivitas pembelajaran bagi peserta didik. Peserta didik dapat dengan mudah berbagi semua informasi penting seperti jadwal pendaftaran, tugas, tugas atau bahkan ujian. Studi tentang penggunaan MIM untuk mendukung pengajaran dan pembelajaran sebagian besar tentang WhatsApp. WhatsApp banyak digunakan daripada aplikasi pesan singkat lainnya karena aplikasi ini berbiaya rendah, mampu mengirim konten multimedia (teks, gambar, audio, video, dll.), Mudah digunakan, diunduh gratis, dan menyediakan layanan komunikasi yang sederhana, menyenangkan, dan dapat diakses (Barhoumi, 2015; Bouhnik \& Deshen, 2014; Tang \& Hew, 2017).

Studi lain tentang penggunaan WhatsApp juga menemukan beberapa informasi penting. Dikatakan bahwa aplikasi tersebut dapat meningkatkan motivasi siswa untuk secara aktif terlibat dalam kegiatan pembelajaran (Chipunza, 2013; Plana, 2013). Studi ini menyoroti fakta bahwa, sebagai sumber belajar, WhatsApp menyediakan kesempatan bagi guru untuk terlibat dalam interaksi yang bermakna. Selain itu, mereka juga berpendapat bahwa alat belajar ini menghilangkan hambatan jarak peserta didik, mendorong siswa untuk aktif dan kolaboratif dalam belajar matematika, menumbuhkan lingkungan belajar konstruktivis sosial, dan membangun kepercayaan diri siswa (Naidoo \& Kopung, 2016).

Kepercayaan diri atau self efficacy ini sangat penting dalam proses pembelajaran, karena permasalahan yang sering terjadi disekolah menurut hasil wawancara yang peneliti lakukan kepada guru IPA di Bandar Lampung adalah siswa tidak aktif saat proses pembelajaran berlangsung, hal ini terjadi karena tidak adanya self efficacy dalam diri siswa. Self efficacy merupakan keyakinan untuk menyelesaikan tugas-tugas yang mempengaruhi kehidupannya (Bandura, 1994). Zimmerman (2000), menyatakan bahwa self efficacy menunjang siswa untuk memaksimalkan kemampuan yang dimilikinya.Self efficacy siswa sangat diharapkan karena sebagai nilai kecakapan hidup tetapi, dalam proses pembelajaran di sekolah selama ini belum dilatihkan sehingga siswa kurang memiliki self efficacy yang baik. Rendahnya self efficacy siswa disebabkan adanya penyimpangan dalam proses pembelajaran, salah satu bentuk penyimpangan dalam pelaksanaan pembelajaran adalah kegiatan inti belum dilaksanakan secara optimal atau memenuhi proses eksplorasi, elaborasi, dan konfirmasi. Siswa belajar hanya menghafal konsep-konsep, mencatat apa yang diceramahkan guru (Wirtha dan Rapi, 2008).

Permasalah ini dapat dapat diatasi guru dengan cara mendesain pembelajaran yang kreatif dan interaktif sehingga mampu memotivasi minat belajar, kepercayaan diri, dan keaktifan siswa. Salah satunya menggunakan mobile instant messaging (MIM) sebagai media dalam pembelajaran di sekolah. Menurut temuan Bansal dan Joshis (2014) di mana pembelajaran mobile menggunakan WhatsApp sangat menarik dan mendidik bagi para siswa. Selain itu, pembelajaran menggunakan group messagging ini menghilangkan hambatan jarak peserta didik, mendorong siswa untuk aktif dan kolaboratif dalam belajar matematika, menumbuhkan lingkungan belajar konstruktivis sosial, dan membangun kepercayaan diri siswa (Naidoo \& Kopung, 2016).

Selain kepercayaan diri siswa, permasalahan lain dalam pembelajaran fisika menurut hasil wawancara guru-guru IPA di Bandar Lampung adalah hasil belajar kognitif siswa pada mata pelajaran fisika lebih kecil dibandingkan pelajaran lain seperti biologi, karena dalam pembelajaran fisika ada teori, perhitungan dan percobaan. Rendahnya hasil belajar kognitif pada siswa juga terjadi pada pembelajaran fisika sesuai dengan hasil penelitian Samudra dkk. (2014). Permasalahan permasalahan yang dihadapi siswa SMA di Singaraja dalam mempelajari fisika terdapat dua masalah yaitu sulit memahami dan tidak suka pelajaran fisika. Selain itu, penelitian yang dilakukan Ismail dkk. (2015). Siswa yang memahami konsep 13,9\% lalu siswa yang miskonsepsi 39,9\% dan siswa yang tidak paham konsep $44,01 \%$. Berdasarkan hasil survei tersebut banyak siswa SMA yang kesulitan dalam mempelajari fisika.

Kesulitan belajar fisika bagi siswa, dapat diatasi guru dengan cara mendesain pembelajaran yang kreatif dan interaktif sehingga dapat meningkatkan kemampuan kognitif siswa. Salah satunya 
menggunakan mobile instant messaging (MIM) sebagai media dalam pembelajaran di sekolah karena pembelajaran ini menarik dan tidak membosankan. (Bansal dan Joshis, 2014). Selain itu Rembe dan Bere (2013) menjelaskan bahwa aplikasi Whatsapp Messenger mampu meningkatkan motivasi belajar siswa, mempercepat terjadinya kelompok belajar dalam membangun dan mengembangkan ilmu pengetahuan. Pembelajaran dengan bantuan aplikasi online seperti WhatsApp Messenger dapat meningkatkan kolaborasi dalam pembelajaran, berbagi pengetahuan dan informasi yang berguna dalam proses pembelajaran secara mudah dan cepat, sehingga mempertahankan kesenangan pembelajaran sepanjang masa.

Penelitian lain mengungkapkan pembelajaran menggunakan MIM dapat meningkatkan prestasi belajar siswa dan mudah diterapkan untuk mempromosikan pengajaran dan pembelajaran (Alabdulkareem, 2015; Amry, 2014; Rambe \& Bere, 2013). Penelitian ini sejalan dengan penelitian Suana dkk, (2019) yang menyatakan bahwa penggunaan MIM berupa Line efektif untuk mendukung pembelajaran fisika dalam pendekatan blended learning. Pembelajaran menggunakan Line dalam topik listrik statis meningkatkan kemampuan kognitif siswa.

Pembelajaran menggunakan MIM berupa whatsapp menggunakan teori belajar pendekatan konstruktivisme sosial. Menurut Trianto (2009) teori kontruktivisme sosial menekankan pada konteks sosial dari pembelajaran. Salah satu prinsip kunci yang diturunkan teori Konstruktivisme sosial adalah penekanan pada hakikat sosial dari pembelajaran. Vygotsky mengemukakan bahwa siswa belajar melalui interaksi dengan orang dewasa atau teman sebaya yang lebih mampu. Berdasarkan teori ini dikembangkanlah pembelajaran kooperatif, yaitu siswa lebih mudah menemukan dan memahami konsep-konsep yang sulit jika mereka saling mendiskusikan masalah tersebut dengan temannya. Pembelajaran kontruktivisme sosial menekankan siswa lebih aktif sedangkan guru hanya sebagai mediator saja.Teori ini sejalan dengan penelitian Alabdulkareem, (2015); Barhoumi, (2015); Naidoo \& Kopung, (2016); Prescott dkk., (2013); Rambe \& Bere, (2013); , Sobaih et al.,(2016). Aplikasi media sosial dapat memicu dan meningkatkan interaksi antara instruktur dan siswa dalam pembelajaran.

Banyak dampak positif dari pembelajaran menggunakan MIM namun, ada fakta yang bertentangan dari MIM untuk alat pembelajaran online. Meskipun baik guru dan siswa bersedia menggunakan WhatsApp dalam proses belajar mengajar, secara praktis, mereka lebih suka menggunakannya untuk interaksi dan tujuan lain selain pendidikan (Alabdulkareem, 2015). Fakta lain yang bertentangan juga disajikan dalam sebuah studi dari Amry (2014). Ditemukan bahwa WhatsApp memberikan lebih banyak dampak negatif pada kinerja siswa daripada efek positifnya (Amry, 2014). Alasan yang mungkin mungkin karena keterbatasan sumber daya tekstual konseptualisasi akademik dan tidak yakin dalam cengkeraman akademik hasil diskusi menggunakan pesan teks di WhatsApp (Rambe \& Bere, 2013). Oleh karena itu, sangat antusias untuk mengeksplorasi kekuatan dan kelemahan aplikasi MIM whatsapp dalam mempertahankan proses belajar-mengajar. Penelitian ini berfokus pada MIM whatsapp untuk mengetahui bagaimana peningkatan self efficacy siswa dan kemampuan kognitif siswa pada materi Hukum Newton dengan menggunkan pembelajaran menggunakan MIM.

\section{METODE}

\section{Desain Penelitian}

Penelitian ini adalah penelitian menggunakan metode Quasi Eksperiment Desaign dengan desain penelitian Nonequivalent Control Group. Penelitian yang dilakukan menggunakan dua kelas yaitu kelas eksperimen dan kelas kontrol yang menjadi sampel. Pembelajaran MIM merupakan pembelajaran campuran. pembelajaran tatap muka-pembelajaran online dalam satu siklus pembelajaran (Suana et al., 2017). Materi pada pembelajaran MIM ini adalah Hukum Newton tentang Gravitasi. Jumlah tatap muka pada kelas eksperimen maupun kontrol sebanyak 4 kali tatap muka. Sebelum melakukan kegiatan pembelajaran siswa diberikan angket self-efficacy dan soal pretest untuk mengukur kemampuan awal siswa.

Kegiatan online pertama siswa mengamati video dan menjawab pertanyaan lalu didiskusikan di 
dalam group whatsapp. Di dalam grup whatsapp siswa saling berdiskusi mengenai video yang diberikan oleh guru. Kegiatan tatap muka siswa melakukan percobaan menggunakan PhET Simulation, menganalisis data yang didapat lalu mempersentasikannya di depan kelas. Untuk kegiatan selanjutnya siswa diberikan video dan pertanyaan melalui whatsapp diluar KBM. Gambar 1 berikut bagan rangkaian prosedur penelitian pada kelas eksperimen maupun kelas kontrol. Pada saat pembelajaran guru hanya sebagai fasilitator, mengamati jalannya diskusi di grup WhatsApp.

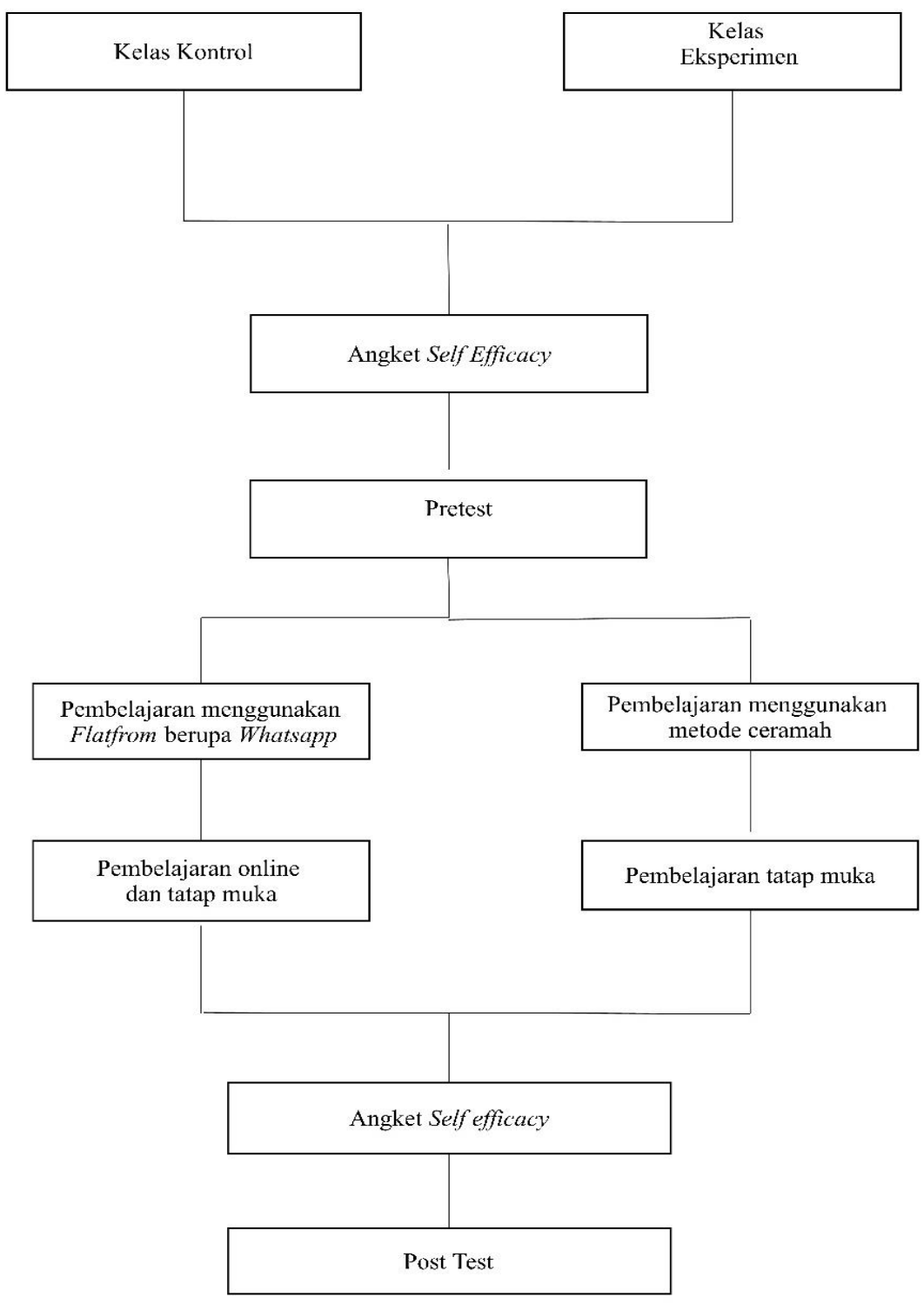

Gambar 1. Bagan Prosedur Penelitian

\section{Subyek penelitian}

Populasi pada penelitian ini yaitu seluruh siswa kelas XI SMAN Bandar Lampung pada semester ganjil untuk Tahun Pelajaran 2018/2019. Sample yang digunakan pada penelitian ini yaitu dengan menggunakan dua kelas pada XI MIA 1 sebagai kelas kontrol dan XI MIA 2 sebagai kelas eksperimen yang berada di SMA N 9 Bandar Lampung.

\section{Data dan instrumen pengumpulan data}

Penelitian ini menggunakan dua bentuk variabel, yaitu variabel bebas dan variabel terikat. Variabel bebas dalam penelitian ini adalah penggunaan media pembelajaran MIM berupa whatsapp, sedangkan variabel terikatnya adalah self efficacy dan kemampuan kognitif. Instrumen penelitian yang digunakan dalam penelitian ini adalah lembar tes untuk mengetahui hasil belajar siswa berupa nilai 
kognitif berbentuk soal uraian yang berjumlah 5 soal, 2 soal dengan aspek analisis diambil dari soal pengembangan (Arina,2018), 1 soal dengan aspek pengetahuan atau ingatan dan 2 soal lagi dengan aspek penerapan. Penilaian self-efficacy menggunakan angket dengan jumlah 21 butir pertanyaan. 21 butir pertanyaan dibagi menjadi 5 aspek yaitu pemahan konsep, kemampuan kognitif tingkat tinggi, keterampilan proses dan kemampuan komunikasi ilmiah. Skala self-efficacy rentang 1-5, point 1 adalah tidak yakin dan point 5 adalah sangat yakin. Angket skala self-efficacy dirujuk dari penelitian (Lin dkk., 2015). Sebelum digunakannya instrumen dalam sampel, instrumen diuji terlebih dahulu menggunakann uji validitas dan uji reliabilitasnya dengan pengujian validitas instrumen bantuan program SPSS.

\section{Teknik Pengumpulan Data dan Analisis Data}

Pengumpulan data dilakukan setelah kegiatan pembelajaran dilaksanakan. Langkah-langkah yang dilakukan dalam pengumpulan data penelitian yaitu dengan memberikan pretest dan angket self efficacy belum pembelajaran dan posttest beserta angket self efficacy kepada seluruh siswa setelah pembelajaran, kemudian dilakukan penilaian. Data yang diperoleh dalam penelitian ini adalah data nilai kognitif siswa sesudah pembelajaran. Data yang diperoleh kemudian dianalisis dengan melakukan (1) uji normalitas, (2) uji homogenitas, (4) Independent Sample T Test, (5) Mann Withney.

\section{HASIL DAN PEMBAHASAN}

Hasil rata-rata persentase selff efficacy yang dicapai siswa sebelum pembelajaran menggunakan MIM adalah 55,73 \% yang artinya adalah siswa memiliki self efficacy sedang. Setelah pembelajaran menggunakan MIM rata-rata persentase self efficacy siswa menjadi 80,01\% yang artinya self efficacy yang dimiliki siswa dalam katagori tinggi. Dari hasil data tersebut dapat disimpulkan bahwa ada perubahan self efficacy siswa setelah pembelajaran MIM. Pada kelas kontrol sebelum pembelajaran rata-rata persentase self efficacy nya adalah $54,06 \%$ termasuk katagori sedang dan setelah pembelajaran rata-rata persentase self efficacy siswa menjadi 67,06 \% termasuk katagori sedang.

\section{Data Self Efficacy Secara Keseluruhan}

Data uji normalitas dan homogenitas dapat dilihat pada tabel 1.

Tabel 1. Uji Normaliatas dan Homogenitas

\begin{tabular}{ccc}
\hline Variabel Penelitian & Normalitas & Homogenitas \\
\hline Pretest & $\checkmark$ & $\checkmark$ \\
Posttest & $\checkmark$ & $\checkmark$ \\
\hline
\end{tabular}

Dari Tabel 2 dapat disimpulkan bahwa data self efficacy secara keseluruhan berdistribusi normal dan homogen.

Data hasil uji independent sampel t-test self-efficacy dapat dilihat pada tabel 2

Tabel 3 Hasil Uji Independent Sampel T-Test Self Efficacy

\begin{tabular}{ccl}
\hline Variabel Penelitian & Asymp. Sig & Keterangan \\
\hline Pretest & 0,912 & Tidak ada perbedaan \\
Posttest & 0,034 & Ada perbedaan
\end{tabular}

Berdasarkan Tabel 2 dapat dilihat bahwa nilai signifikansi pretest lebih dari 0,05 maka dapat disimpulkan bahwa $\mathrm{H}_{0}$ diterima hal ini berarti tidak ada perbedaan antara kelas eskperimen maupun kelas kontrol. Nilai signifikasi self efficacy setelah pembelajaran adalah kurang dari 0,05 maka dapat disimpulkan bahwa $\mathrm{H}_{0}$ ditolak, hal ini berarti dapat diuraikan bahwa untuk hipotesis pertama yaitu ada perbedaan self efficacy siswa sebelum dan setelah pembelajaran menggunakan MIM.

\section{Data Self Efficacy Per-aspek}

Data uji normal dan homogenitas dapat dilihat pada tabel 3. 
Tabel 3. Uji Normalitas dan Homogenitas

\begin{tabular}{lcc}
\multicolumn{1}{c}{ Aspek } & Normalitas & Homogenitas \\
\hline $\begin{array}{l}\text { Pemahaman konsep } \\
\text { Kemampuan kognitif } \\
\text { tingkat tinggi }\end{array}$ & $\times$ & $\checkmark$ \\
$\begin{array}{l}\text { Keterampilan Proses } \\
\text { Kemampuan komunikasi ilmiah }\end{array}$ & $\checkmark$ & $\checkmark$ \\
& $\times$ & $\checkmark$ \\
\hline
\end{tabular}

Dari tabel 3 dapat disimpulkan bahwa aspek pemahaman konsep dan kemampuan komunikasi ilmiah memiliki data tidak normal sehingga untuk membandingkan hasil penelitian kelas eksperimen dan kontrol menggunakan uji mann withney. Aspek kemampuan kognitif tingkat tinggi dan keterampilan proses memiliki data normal dan homogen sehingga uji yang digunakan uji independent sample $t$-test.

Data uji mann withney dapat dilihat pada tabel 4

Tabel 4. Uji Mann Withney

\begin{tabular}{lcl}
\hline \multicolumn{1}{c}{ Aspek } & Nilai Sig & Keterangan \\
\hline Pemahaman konsep & 0,912 & Tidak ada perbedaan \\
Kemampuan komunikasi IImiah & 0,04 & Ada perbedaan \\
\hline
\end{tabular}

Dari tabel 4 dapat disimpulkan bahwa pada aspek pemahamn konsep tidak ada perbedaan self efficacy siswa pada kelas eksperimen maupun kelas kontrol. Aspek kemampuan komunikasi ilmiah setelah pembelajaran menggunakan MIM ada perbedaan self efficacy siswa pada kelas eksperimen dan kelas kontrol.

Data uji independent sample $t$-test dapat dilihat pada tabel 5

Tabel 5. Uji Independent Sample T-Test

\begin{tabular}{lll}
\hline \multicolumn{1}{c}{ Aspek } & Nilai sig & Keterangan \\
\hline Kemampuan kognitif tingkat tinggi & 0,02 & Ada perbedaan \\
Keterampilan proses & 0,00 & Ada perbedaan \\
\hline
\end{tabular}

Dari tabel 5 dapat disimpulkan bahwa setelah pembelajaran menggunakan MIM ada perbedaan antara kelas eksperimen dan kelas kontrol pada aspek kemampuan kognitif tingkat tinggi dan keterampilan proses.

\section{Data Kemampuan Kognitif Secara keseluruhan}

Hasil Uji Hipotesis dengan Independent Sample T-Test dapat dilihat pada tabel 6

Tabel 6 Hasil Uji Independent Sampel T-Test Self Efficacy

\begin{tabular}{crl}
\hline Variabel Penelitian & Asymp. Sig & Keterangan \\
\hline Pretest & 0,37 & Tidak ada perbedaan \\
Posttest & 0,00 & Ada perbedaan \\
\hline
\end{tabular}

Berdasarkan Tabel 6 dapat dilihat bahwa nilai signifikasi pretest lebih dari 0,05 maka dapat disimpulkan bahwa $\mathrm{H}_{0}$ diterima, hal ini berarti tidak ada perbedaan kemampuan kognitif pada kelas eksperimen maupun kelas kontrol. Nilai signifikansi postest kurang dari 0,05 maka dapat disimpulkan bahwa $\mathrm{H}_{0}$ ditolak, ini berarti dapat diuraikan bahwa untuk hipotesis kedua yaitu ada perbedaan kemampuan kognitif siswa sebelum dan setelah pembelajaran menggunakan pembelajaran MIM .

\section{Data Uji N-Gain}

Peningkatan self efficacy siswa dapat dilihat dari selisih antara hasil sebelum diberi perlakuan 
Rika Dwi Kurniati, Wayan Suana, dan Nengah Maharta

dengan hasil setelah diberi perlakuan.

Tabel 7. Data Rata-rata N-gain Self Efficacy

\begin{tabular}{ccccc}
\hline Kelas & Gain Terendah & Gain Tertinggi & Rata-rata N-gain & Kategori \\
\hline Kontrol & 1 & 40 & 0,24 & Rendah \\
Eksperimen & 1 & 69 & 0.56 & Sedang \\
\hline
\end{tabular}

Berdasarkan Tabel 7 dapat dilihat hasil $N$-gain self efficacy dari kelas kontrol memiliki self efficacy kategori sedang, sedangkan pada kelas kontrol memiliki self efficacy katagori sedang.

Data Kemampuan Kognitif Berdasarkan Level Kognitif Soal

Hasil uji normalitas dan uji homogenitas dapat dilihat pada tabel 8.

Tabel 8 Uji Normalitas dan Homogenitas

\begin{tabular}{lcc}
\hline Aspek & Normalitas & Homogenitas \\
\hline Level Kognitif Tinggi & $\times$ & $\checkmark$ \\
Level Kognitif Rendah & $\times$ & $\checkmark$ \\
\hline
\end{tabular}

Dari data Tabel 8 dapat disimpulkan bahwa pada data aspek level kognitif tinggi dan level kognitif rendah tidak berdistribusi normal sehingga peneliti menggunakan uji man withney untuk mengetahui perbedaan kelas antara eksperimen dan kontrol setelah pembelajaran menggunakan MIM.

Data Uji Mann-Withney dapat dilihat pada Tabel 9

Tabel 9 Uji Mann Whitney $U$ Test

\begin{tabular}{ccc}
\hline & Asymp. Sig & Keterangan \\
\hline Soal Level Kgnitif Rendah & 0,00 & Ada Perbedaan \\
Soal Level Kognitif Tinggi & 0,00 & Ada Perbedaan \\
\hline
\end{tabular}

Dari tabel 9 dapat dilihat nilai sig < 0,05 maka dapat disimpulkan bahwa pada siswa yang mengerjakan soal level kognitif rendah pada nomor soal 1 sampai 3 dan soal kognitif tinggi pada nomor soal 4 dan 5 memiliki perbedaan rata-rata antara kelas kontrol maupun kelas eksperimen. Menurut Taksonomi bloom menyatakan bahwa level kognitif rendah berada pada level 1. Pada level ini hanya kemampuan standar minimum siswa dalam menguasi pelajaran. Level kognitif tinggi berada pada level 3 , pada level ini siswa memiliki penalaran dan logika dalam menjawab soal.

\section{Pembahasan}

Hasil rata-rata persentase self efficacy yang dicapai siswa sebelum pembelajaran menggunakan MIM peneliti memberikan angket self efficacy baik pada kelas eksperimen maupun kelas kontrol. Hasil yang didapatkan sebelum pembelajaran MIM adalah $55,73 \%$ yang artinya adalah siswa memiliki self efficacy sedang. Setelah pembelajaran menggunakan MIM rata-rata persentase self efficacy siswa menjadi 80,1\% yang artinya self efficacy yang dimiliki siswa katagori tinggi. Pada kelas kontrol sebelum pembelajaran rata-rata persentase self efficacy adalah 54,06 \% termasuk katagori sedang dan setelah pembelajaran rata-rata persentase self efficacy siswa menjadi $67,06 \%$ termasuk katagori sedang.

Hasil pengujian hipotesis yaitu uji Independent Sampel T-Test yang memperoleh nilai signifikansi kurang dari 0,05 maka dapat disimpylkan bahwa ada perbedaan self efficacy siswa antara kelas eksperimen dan kelas kontrol. Hal ini juga dapat dilihat dengan uji $\mathrm{N}$-Gain. Pada kelas kontrol, hasil yang didapat 0,247 dengan katagori rendah, sedangkan pada kelas eksperimen hasil yang didapat 0,564 dengan katagori sedang. Dari hasil uji Independent Sampel T-Test dan perhitungan N-Gain dapat disimpulkan bahwa ada perbedaan self efficacy pada kelas kontrol dan eksperimen. Terdapat pula peningkatan self efficacy siswa dengan pembelajaran menggunakan platform berbantuan whatsapp dibandingkan dengan pembelajaran konvesional.

Peningkatan self efficacy pada kelas eksperimen dikarenakan pada saat pembelajaran siswa dituntut aktif dalam menyampaikan pendapat, bertanya dan diskusi di dalam group whatsapp. Dengan 
demikian siswa yang tidak memiliki rasa kepercayaan diri saat di kelas untuk menyampaikan pendapat secara langsung dapat mengungkapkan pendapatnya secara bebas di dalam group whatsapp tanpa rasa ragu. Pada kelas eksperimen siswa sangat antusias dalam pembelajaran dibandingkan pada kelas kontrol yang menggunakan pembelajaran konvensional. Pembelajaran menggunakan MIM ini tidak membosakan karena dalam pembelajaran siswa tidak hanya duduk di dalam kelas mendengarkan guru menjelaskan. Siswa dapat belajar dimanapun dan kapanpun tanpa batasan jarak.

Studi lain tentang penggunaan WhatsApp juga menemukan beberapa informasi penting. Dikatakan bahwa aplikasi tersebut dapat meningkatkan motivasi siswa untuk secara aktif terlibat dalam kegiatan pembelajaran (Chipunza, 2013; Plana, 2013). Selanjutnya, intervensi WhatsApp dalam pembelajaran matematika pada guru pre-service juga telah dieksplorasi oleh Naidoo dan Kopung (2016). Studi ini menyoroti fakta bahwa, sebagai sumber belajar, WhatsApp menyediakan kesempatan bagi guru pre-service untuk terlibat dalam interaksi yang bermakna. Selain itu, mereka juga berpendapat bahwa alat belajar ini menghilangkan hambatan jarak peserta didik, mendorong siswa untuk aktif dan kolaboratif dalam belajar matematika, menumbuhkan lingkungan belajar konstruktivis sosial, dan membangun kepercayaan diri siswa (Naidoo \& Kopung, 2016)

Hal ini serupa dengan hasil penelitian dari Jarwani (2016) pelaksanaan pembelajaran menggunakan pembelajaran tatap muka-online lebih meningkatkan self efficacy siswa sehingga memiliki keyakinan mengenai kemampuannya dalam mengorganisasi dan menyelesaikan suatu tugas yang diperlukan untuk mencapai hasil tertentu dalam berbagai bentuk dan tingkat kesulitan.

Dapat disimpulkan bahwa secara keseluruhan ada peningkatan self efficacy siswa pada pembelajaran menggunkan MIM dibandingkan pembelajaran secara konvensional, akan tetapi saat diujikan peraspek ada beberapa aspek yang tidak berpengaruh dan berpengaruh. Aspek pemahaman konsep pembelajaran menggunakan $M I M$ tidak ada pengaruh atau perbedaan pada kelas eksperimen maupun kontrol. Aspek kemampuan komunikasi ilmiah setelah pembelajaran ada perbedaan self efficacy siswa pada kelas eksperimen dan kelas kontrol. Hal ini dikarenakan pada kelas eksperimen siswa lebih aktif dalam pembelajaran, bebas untuk saling berdiskusi, menyampaikan pendapat dan bertukar ide. Penlitian ini sejalan dengan Naidoo \& Kopung, (2016) menyatakan bahwa pembelajaran menggunakan whatsapp dapat mendorong siswa untuk aktif dan kolaboratif dalam belajar.

Sama halnya pada aspek kemampuan kognitif tingkat tinggi dan keterampilan proses. Setelah pembelajaran menggunakan MIM ada peningkatan kemampuan kognitif tingkat tinggi dan keterampilan proses pada eksperimen dibandingkan pada kelas kontrol. Hal ini dikarenkan siswa pada kelas eksperimen saat pembelajaran siswa lebih mudah bertukar informasi mengenai materi yang sulit dipelajari. Pembelajaran menggunkan whatsapp ini juga membuat siswa mudah saling berinteraksi saat pembelajaran tanpa hambatan jarak dan waktu. Hal ini sejalan dengan studi lain tentang penggunaan whatsapp, bahwa aplikasi whatsapp dapat meningkatkan motivasi siswa untuk secara aktif terlibat dalam proses pembelajaran (Chipunza, 2013; Plana, 2013). Selain itu, dengan menggunakan WhatsApp, para pendidik bisa mendapatkan pemahaman yang lebih baik tentang siswa mereka dan juga menciptakan lingkungan yang menguntungkan untuk proses pembelajaran sehingga hasil belajar siswa juga lebih baik (Bouhnik \& Deshen, 2014)

Berdasarkan penelitian yang telah dilakukan diperoleh rata-rata kemampuan kognitif siswa pada kelas eksperimen lebih tinggi daripada kelas kontrol, data rata-rata nilai pretest dan postest pada kelas eksperimen adalah 56,83 dan 82,3 . Sedangkan pada kelas kontrol rata-rata nilai pretest dan posttest siswa sebesar 58,16 dan 72 . Hal ini didukung oleh hasil perhitungan pengujian hipotesis menggunakan uji Idependent Sample T-Test dengan data hasil belajar siswa sebelum dan setelah belajar menggunakan MIM, dari uji Idependent Sample T-Test dihasilkan bahwa nilai signifikansi pretest lebih dari 0.05 yang artinya sebelum diberikan treatment kemampuan siswa pada kelas eksperimen maupun kontrol sama. Setelah diberikan treatment hasil yang diperoleh dari uji Idependent Sample T-Test signifikansi kurang dari 0,05 maka dapat disimpulkan $\mathrm{H}_{0}$ ditolak, yang artinya ada perbedaan kemampuan kognitif siswa sebelum dan setelah pembelajaran menggunakan pendekatan pembelajaran MIM. Peningkatan hasil belajar kemampuan kognitif dapat dilihat dengan hasil uji $\mathrm{N}$-Gain 
setelah pembelajaran MIM yaitu 0,568 dengan katagori sedang, sedangkan pada kelas kontrol yang tidak menggunakan pembelajaran MIM hasil Uji N-Gain 0,291 dengan katagori rendah.

Peningkatan kemampuan kognitif siswa pada kelas eksperimen diakarenakan pada proses pembelajaran berlangsung siswa merasa senang dan tetarik pada pembelajaran, sehingga siswa dapat mengikuti pembelajaran dengan baik. pembelajaran ini juga sangat memudahkan siswa karen alat yang digunakan dimiliki dan selalu dibawa siswa setiap saat. Pembelajaran melalui whatsapp juga mudah untuk saling bertukar ide saat siswa kesulitan dalam mengerjakan soal yang diberikan oleh guru. Hal ini sejalan dengan Crescente \& Lee (2011) Manfaat menerapkan pembelajaran mobile adalah menyediakan siswa untuk studi yang dipersonalisasi, memperluas lingkungan belajar ke mana saja dan kapan saja , biaya lebih murah, dan ukuran lebih kecil dan lebih ringan daripada menggunakan komputer (Stošić \& Bogdanović, 2013). Peneliti lain mengungkapkan bahwa dengan menggunakan perangkat seluler, siswa dapat membangun dan memiliki kesempatan untuk berbagi informasi dan pengetahuan dengan mudah (Pence, 2007). Selain itu, Amry (2014) menyatakan bahwa perangkat seluler memberikan mobilitas dan interaktivitas pembelajaran bagi peserta didik. Peserta didik dapat dengan mudah berbagi semua informasi penting seperti jadwal pendaftaran, tugas, tugas atau bahkan ujian.

Peneliti menguji kemampuan siswa berdasarkan katogori soal level kognitif randah dan tinggi. Melalui uji mann withney untuk mengetahui adakah pengaruh pembelajaran MIM dengan pembelajaran konvensional. Hasil yang didapatkan nilai sig < 0,05 maka dapat disimpulkan bahwa siswa yang mengerjakan soal level kognitif rendah dan soal level kognitif tinggi memiliki perbedaan rata-rata antara kelas kontrol maupun kelas eksperimen. Hasil belajar siswa pada kelas eksperimen lebih baik dibandingkan pada kelas kontrol. Penelitian ini sejalan dengan penelitian Rambe dan Bere (2013), bahwa aplikasi Whatsapp Messenger mampu meningkatkan motivasi belajar siswa, mempercepat terjadinya kelompok belajar dalam membangun dan mengembangkan ilmu pengetahuan. Pembelajaran dengan bantuan aplikasi online seperti WhatsApp Messenger dapat meningkatkan kolaborasi dalam pembelajaran, berbagi pengetahuan dan informasi yang berguna dalam proses pembelajaran secara mudah dan cepat, sehingga dapet meningkatakan hasil belajar siswa.

Penelitian lain menunjukkan bahwa penggunaan MIM Line efektif untuk mendukung pembelajaran fisika dalam pendekatan blended learning. Penggunaan Line dalam topik listrik statis meningkatkan kemampuan kognitif siswa (Suana dkk, 2019) .Peneliti lain mengungkapkan bahwa pembelajaran mobile secara efektif melatih pemikiran kritis siswa dan juga mendapatkan tanggapan positif dari peserta didik (Kustijono \& Zuhri, 2018). Studi lain tentang penggunaan WhatsApp juga menemukan beberapa informasi penting. Dikatakan bahwa aplikasi tersebut dapat meningkatkan motivasi siswa untuk secara aktif terlibat dalam kegiatan pembelajaran (Chipunza, 2013; Plana, 2013). Selain itu, dengan menggunakan WhatsApp, para pendidik bisa mendapatkan pemahaman yang lebih baik tentang siswa mereka dan juga menciptakan lingkungan yang menguntungkan untuk proses pembelajaran (Bouhnik \& Deshen, 2014).

\section{PENUTUP}

Ada pengaruh peningkatan self efficacy siswa dengan pembelajaran menggunakan MIM, ditunjukkan dengan hasil uji Independent Sample T-Test nilai signifikasi kurang dari 0,05. Hal ini dapat disimpulkan ada perbedaan rata-rata self efficacy yang signifikan antara pembelajaran menggunakan MIM dan pembelajaran konvensional. Perolehan rata-rata $\mathrm{N}$-gain self efficacy sebesar 0,56 dengan kategori peningkatan self efficacy sedang.

Selanjutnya juga ada pengaruh peningkatan kemampuan kognitif siswa dengan pembelajaran menggunakan MIM, ditunjukkan dengan hasil uji Independent Sample T-Test nilai signifikasi kurang dari 0,05 . Hal ini dapat disimpulkan ada perbedaan rata-rata kemampuan kognitif yang signifikan antara pembelajaran menggunakan MIM dan pembelajaran konvensional. 
Saran bagi guru, dapat menerapkan pembelajaran MIM dengan menggunakan media sosial yang diminati siswa dan pada saat pembelajaran berlangsung guru harus lebih fokus memantau siswa yang kurang aktif saat berdiskusi di grup. Sedangkan saran bagi peneliti selanjutnya dapat menggunakan variabel yang berbeda untuk lebih mengetahui pengaruh dari pembelajaran menggunakan MIM.

\section{DAFTAR PUSTAKA}

Amry, A. B. (2014). The impact ofwhatsapp mobile social learning on the achievement and attitudes of female students compared with face to face learning in the classroom. European Scientific Journal, ESJ, 10(22), 116-136.

Abdelraheem, A. Y., \& Ahmed, A. M. (2018). The Impact of Using Mobile Social Network Applications on Students' Social-Life. International Journal of Instruction, 11(2), 1-14. https://doi.org/10.12973/iii.2018.1121a

Alabdulkareem, S. A. (2015). Exploring the use and the impacts of social media on teaching and learning science in Saudi. Procedia-Social and Behavioral Sciences, 182, 213-224. https://doi.org/10.1016/i.sbspro.2015.04.758

Bansal, T., \& Joshi, D. (2014). A study of students experiences of WhatsApp mobile learning. Global Journal of Human-Social Science Research. 14(4).

Barhoumi, C. (2015). The Effectiveness of WhatsApp Mobile Learning Activities Guided by Activity Theory on Students' Knowledge Management. Contemporary Educational Technology, 6(3), 221-238.

Bouhnik, D., \& Deshen, M. (2014). WhatsApp goes to school: Mobile instant messaging between teachers and students. Journal of Information Technology Education: Research, 13(1), 217231. https://doi.org/10.28945/2051

Chipunza, P. R. C. (2013). Using mobile devices to leverage student access to collaborativelygenerated resources: A case of WhatsApp instant messaging at a South African University. In International Conference on Advanced Information and Communication Technology for Education (ICAICTE 2013).

Crescente, M. L., \& Lee, D. (2011). Critical issues of m-learning: design models, adoption processes, and future trends. Journal of the Chinese institute of industrial engineers, 28(2), 111-123. https://doi.org/10.1080/10170669.2010.548856

Samudra, G. B., Suastra, I. W., \& Suma, K. (2014). Permasalahan-permasalahan yang dihadapi siswa SMA di kota singaraja dalam mempelajari fisika. Jurnal Pendidikan dan Pembelajaran IPA Indonesia, 4(1).

Kustijono, R., \& Zuhri, F. (2018). The use of Facebook and WhatsApp application in learning process of physics to train students' critical thinking skills. In IOP Conference Series: Materials Science and Engineering (Vol. 296, No. 1, p. 012025). IOP Publishing. https://doi.org/10.1088/1757$\underline{899 X / 296 / 1 / 012025}$

OECD. (2016). Results Excellence and Equity In Education. OECD Publishing.

Naidoo, J., \& Kopung, K. J. (2016). Exploring the use of WhatsApp in mathematics learning: A case study. Journal of Communication, 7(2), 266-273. https://doi.org/10.1080/0976691X.2016.11884907

Rambe, P., \& Bere, A. (2013). Using mobile instant messaging to leverage learner participation and transform pedagogy at a South African University of Technology. British Journal of Educational Technology, 44(4), 544-561. https://doi.org/10.1111/bjet.12057 
Pence, H. E. (2007). Preparing for the real Web generation. Journal of Educational Technology Systems, 35(3), 347-356. https://doi.org/10.2190/7116-G776-7P42-V110

Prescott, J., Wilson, S., \& Becket, G. (2013). Facebook use in the learning environment: do students want this?. Learning, Media and Technology, 38(3), 345-350. https://doi.org/10.1080/17439884.2013.788027

Sobaih, A. E. E., Moustafa, M. A., Ghandforoush, P., \& Khan, M. (2016). To use or not to use? Social media in higher education in developing countries. Computers in Human Behavior, 58, 296305. https://doi.org/10.1016/j.chb.2016.01.002

Suana, W., Distrik, I. W., Herlina, K., Maharta, N., \& Putri, N. M. A. A. (2019). Supporting Blended Learning Using Mobile Instant Messaging Application: Its Effectiveness and $\begin{array}{llll}\text { Limitations. International Journal of Instruction, 12(1), } & 1022 .\end{array}$ https://doi.org/10.29333/iii.2019.12165a

Suana, W., Maharta, N., Nyeneng, I. D., \& Wahyuni, S. (2017). Design And Implementation Of Schoology-Based Blended Learning Media For Basic Physics I Course. Jurnal Pendidikan IPA Indonesia, 6(1), 170-178. https://doi.org/10.15294/jpii.v6i1.8648

Lin, T. J., Liang, J. C., \& Tsai, C. C. (2015). Identifying Taiwanese university students' physics learning profiles and their role in physics learning self-efficacy. Research in Science Education, 45(4), 605-624. https://doi.org/10.1007/s11165-014-9440-z

Wirtha, I. M., \& Rapi, N. K. (2008). Pengaruh model pembelajaran dan penalaran formal terhadap penguasaan konsep fisika dan sikap ilmiah siswa sma negeri 4 singaraja. Jurnal Penelitian dan Pengembangan Pendidikan, 1(2), 15-29. 